\title{
UCP1 wt Allele
}

National Cancer Institute

\section{Source}

National Cancer Institute. UCP1 wt Allele. NCI Thesaurus. Code C112493.

Human UCP1 wild-type allele is located within 4q28-q31 and is approximately $9 \mathrm{~kb}$ in length. This allele, which encodes mitochondrial brown fat uncoupling protein 1 , is involved in thermogenic proton transport. Polymorphism in the gene is associated with susceptibility to both obesity and type II diabetes mellitus. 